\title{
Current clinical and therapeutic issues in measles
}

 \\ From The 9th Edition of the Scientific Days of the National Institute for Infectious Diseases Prof Dr Matei Bals \\ Bucharest, Romania. 23-25 October 2013
}

\section{Background}

Known since antiquity (the etiological agent was discovered much later), measles continues to be a problem of infectious pathology present in Romania and in many other countries.

\section{Methods}

We have studied a total of 503 cases admitted to the Infectious Diseases II Clinic of Infectious Diseases and Pneumology Hospital of Timişoara between 2011-2012.

\section{Results}

Measles still represents a common disease among infants and young children, fact confirmed in our study by the high number of cases: 331 (65\%). The most common complications in children were the respiratory and ENT infections. The number of measles cases was higher in 2011 compared to 2012 which coincides with data reported by other countries.

\section{Conclusion}

The absence of vaccination from multiple reasons explained the increased number of measles cases (with significant variations in county level). Eradication of measles has been proposed by many countries, e.g. USA, France for over 10 years without being actually realized. In 1993, the measles virus was more neurotropic (there were many cases of deadly encephalitis) compared to the virus strain from 2011-2012.

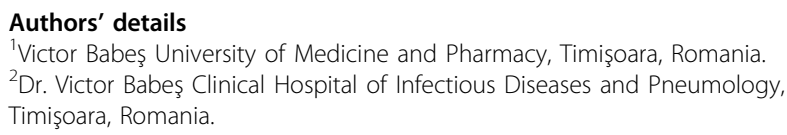

doi:10.1186/1471-2334-13-S1-P106

Cite this article as: Nicolescu et al:: Current clinical and therapeutic issues in measles. BMC Infectious Diseases 2013 13(Suppl 1):P106.
Submit your next manuscript to BioMed Central and take full advantage of:

- Convenient online submission

- Thorough peer review

- No space constraints or color figure charges

- Immediate publication on acceptance

- Inclusion in PubMed, CAS, Scopus and Google Scholar

- Research which is freely available for redistribution
() Biomed Central

\section{Biomed Central}

